\title{
LEGAL AND SOCIO-ECONOMIC PROBLEMS THAT ARISE DURING THE DETECTION OF SIGNS OF VIOLATIONS OF CUSTOMS RULES, AND IDENTIFYING PROPERTY WHICH HAS NO OWNER OR OWNER WHO IS UNKNOWN BY BORDER AND FISCAL AUTHORITIES
}

Keywords: customs control, border control, violation of customs rules, interaction, state border guard, customs.

\begin{abstract}
In this research paper the author considers the problematic aspects of interaction of bodies (units) of state border protection and customs of the State Customs Service of Ukraine during the detection of signs of violations of customs rules, as well as the indentifying property that has no owner or owner unknown at border crossings. entry-exit checkpoint, in the controlled border area. At the same time, the current state of legal regulation of this issue, the main legislative developments in this area, which took place in connection with the joint order of the Ministry of Finance and the Ministry of Internal Affairs of Ukraine number 849/828, foreign approaches to cooperation between customs and border units. Based on the study, it was concluded that the issues of cooperation between state border guards and customs of the State $\mathrm{Cu}$ stoms Service of Ukraine are regulated by the updated Procedure number 849/828, approved by a joint order of the Ministry of Internal Affairs and the Ministry of Finance of Ukraine. a number of powers from the administrative-operational group to draw up reports on administrative offenses, to send an act of detection, and on the property of the owner, who is unknown or as has no owner - transfer of property to the relevant department of the State Customs Service of
\end{abstract}

1 Ph.D. in Law, National Academy of the State Border Guard Service of Ukraine named after Bohdan Khmelnytskyi, gavrik.roman@gmail.com. ORCID: 0000-0003-15570594.

2 Ph.D. in Law, National Academy of the State Border Guard Service of Ukraine named after Bohdan Khmelnytskyi, svet-petre@meta.ua. ORCID: 0000-0002-7329-0219. 
Ukraine, to other officials of state border guards, and also extended the validity of this document not only to cases of violations of customs rules, property whose owner has no owner or whose owner is unknown, detected at checkpoints across the state border of Ukraine, but also for similar cases detected at the checkpoint of entry-exit, in the controlled border area. At the same time, the mentioned Procedure number 849/828 does not solve a number of urgent issues of such interaction, such as: insufficiently effective coordination of work of state border guards and customs of the State Customs Service of Ukraine on ensuring unity of customs and border control, impossibility to send a representative protection of the state border (units of protection of the state border) and customs of the State Customs Service of Ukraine, carrying out separate control in cases when it is necessary to carry out joint control, lack of interest in such interaction, lack of a specific list of reasons when a joint inspection should be conducted, lack of sanctions for failure to conduct a joint inspection in case of detection of goods moving in violation of customs rules and border legislation without sufficient reasons. Therefore, a solution to these problems is proposed.

\section{INTRODUCTION}

At the present stage of development of the Ukrainian state, in terms of strengthening globalization processes in the world economy, including taking into account the approximation of the economy, law, political system and social sphere of Ukraine to European standards, implementation of Association Agreements, readmission, visa-free regime between Ukraine on the one hand and the European Union on the other, certain directives and regulations of the European Union, which regulate a number of issues of political, social and economic nature, economic ties are being strengthened between Ukraine and the member states of the European Union, between economic entities of these countries, which in turn leads to an increase in the movement of goods, currency, cultural values, vehicles and other items across the customs border of Ukraine. This circumstance necessitates the development of a mechanism to combat violations of the law governing such movement, fiscal, border and other measures of official control over goods and other items imported into the customs territory of Ukraine and exported outside the customs territory of Ukraine. Given the military aggression by the Russian Federation and its supported military-terrorist formations, the violation of the state border regime in the temporarily occupied territories, the emergence of 
a terrorist threat, including the use of goods and other items moving across the state border, the issue of effective interaction state bodies in the conduct of state (especially border and customs) control over the movement of goods, other objects and vehicles across the customs border of Ukraine is becoming increasingly important.

This study is also relevant in terms of developing a better mechanism for cooperation between border and fiscal units in other countries, as was noted Aurelija Pūraite, the European Union is currently facing a number of problems related to effective border management, the need for appropriate economic and financial measures and control of migration flows, which is crucial for achieving the common goals of public security, stability, respect for European values and the rule of law (Aurelija Pūraite, 2017).

\section{MATERIALS AND METHODS}

The researched materials are the works of Ukrainian and foreign scientists who studied the problem under consideration.

In the process of research general and specific scientific methods were used, namely: the comparative method was used in the analysis of scientific categories, definitions and approaches; the dialectical method allowed us to consider the state of scientific research on this issue; the method of analysis and synthesis, as well as the logical method were used to develop a better mechanism of interaction between border and fiscal units in Ukraine; the method of legal modeling was useful for the conclusions of the study.

Certain issues of cooperation between fiscal and border units on the implementation of joint customs and border control over goods and other items moving across the customs border, have been the subject of many scientists. In particular, general issues of ensuring the interaction of state border guards of Ukraine with other law enforcement agencies and military formations have been the subject of monographic research by such scientists as Rostyslav Kalyuzhny, Iryna Kushnir and Valentyn Zolka, and foreign experience in conducting effective customs control, including in the aspect of interaction between border and fiscal authorities - in the 
monograph of Maryna Boykova. Some issues of cooperation between the customs of the State Customs Service of Ukraine and state border guards were touched upon in their works by Oleksandr Avdeev, Yakiv Halaniuk, Humeniuk R.A., Karnaukhov O.V., Lavrynets A.E., Mota A.F., Nechitaylenko A.O., Pedeshko A.I., Prodayko S.V., Savchuk S.S., Servatyuk L.V., Serikh O.V., Fedotov O.P., Tsarenko S.I. , similar interaction between fiscal and border units of other countries was studied in particular by. Adamchyk M., Bukanova O.A., Bobrova O.G.,. Grecius S., Purate A., Semenyuk D.P., Seniutiene D. and others. Despite the high scientific value of the above research, It should be noted that, unfortunately, they hardly touch upon such an important aspect of cooperation between the customs of the State Customs Service of Ukraine and the state border guards, as an interaction during the detection of signs of violations of customs regulations, the detection of property that has no owner or whose owner is unknown, as well as other issues related to the need for joint customs and border control, and even if they were the subject of the study, they were of a sufficiently overview nature..

Given that on October 18, 2018, a joint order of the Ministry of Internal Affairs of Ukraine and the Ministry of Finance of Ukraine number 849/828 (hereinafter - the Procedure № 849/828) approved a new procedure for this interaction, there is a need to analyze it and development of proposals for its improvement in terms of ensuring the effective operation of state border guards and customs of the State Customs Service of Ukraine, ensuring compliance with customs legislation and legislation on border issues, prevention of violations in this areai, including prevention of smuggling, ensuring economic and national security of Ukraine, in particular on the administrative border with the Autonomous Republic of Crimea, the line of demarcation between the controlled territory of Ukraine and the territory of certain districts of Donetsk and Luhansk regions controlled by so-called "DPR" and "LPR" and the Russian Federation.

Thus, according to the reporting data of the State Border Guard Service of Ukraine for the first quarter of 2020, the state border guards identified and transferred to other law enforcement agencies within the competence of the goods, moved in violation of the established rules, in the amount 
of UAH 74.11 million (for the corresponding period of 2019 - UAH 72.67 million). In particular, in 2019, goods worth UAH 325.7 million were seized, including 17.2 million packs of cigarettes, almost $682.6 \mathrm{~kg}$ of amber, and more than 67.3 thousand liters of alcohol. In addition, illegal movement of goods totaling UAH 71.7 million was stopped in the prescribed manner through the demarcation line in the area of the Joint Forces Operation (General Results, 2019). This circumstance confirms the relevance of this research.

\section{LEGAL BASIS OF INTRACTION}

Given the variety of types of state control carried out at the state border, there is a need to optimize such control. As Pryimachenko D.V. rightly points out, the implementation of tasks assigned to fiscal authorities is impossible without cooperation and interaction with a number of state institutions, and the issue of organizing information in the process of customs procedures and improving its efficiency is a priority (Pryimachenko, 2014).

The legal basis for the interaction between the bodies of the State Customs Service of Ukraine and the State Border Guard Service on violations of customs legislation and legislation on border issues are Art. 558 of the Customs Code of Ukraine, paragraphs. 191.1.23 of the Tax Code of Ukraine, paragraph 6 and paragraph 33 of Part 1 of Art. 20 of the Law of Ukraine "On the State Border Guard Service of Ukraine" and Art. 271 of the Law of Ukraine "On the State Border of Ukraine". The content of these documents follows from Art. 8 of the Protocol of Amendment to the Marrakesh Agreement Establishing the World Trade Organization, to which Ukraine has acceded, which states that each member shall ensure that its bodies and institutions responsible for border control and procedures relating to imports, exports and transit goods, cooperate with each other and coordinate their activities in order to facilitate trade and Article 10 of this Protocol, which defines the need for common border procedures (Protocol Marrakech, 2014), (Coordinated border management, 2017). 
The above legal acts stipulate that the fiscal authorities in the performance of their tasks interact, including through the exchange of information, with law enforcement agencies in the manner prescribed by law, including in the case of detection during customs control signs of violations that do not belong to the competence of the bodies of the State Customs Service of Ukraine, and the State Border Guard Service of Ukraine in the person of its central body, territorial bodies, state border guards and other subdivisions of state border protection within the powers established by law coordinates the activities of state bodies exercising various types of control when crossing the state border of Ukraine or participate in ensuring the state border regime, border regime and regime at checkpoints across the state border of Ukraine; in cooperation with the fiscal authorities have the right: in the case of vehicles, goods and other items moving across the state border of Ukraine, under customs control together with fiscal authorities to carry out inspection, in case of need and support of the specified vehicles, the goods and things, to take measures to prevent the illegal movement across the state border of Ukraine of goods in respect of which legislation is prohibited and restricted, to seize such goods in the event of an attempt to move them across the state border of Ukraine or independently in the course of operational and investigative measures and transfer them to the destination in the prescribed manner.

General issues of such interaction are also defined in paragraph 9.3.1. Procedure for actions of officials of state border protection bodies of the State Border Guard Service of Ukraine regarding the establishment of the regime at checkpoints across the state border, exercising control over its observance, as well as organizing and ensuring interaction and coordination of control bodies and services that carry out various types of control or participate in ensuring the regime at checkpoints across the state border ", which defines general issues of interaction of the State Border Guard Service of Ukraine with others authorities, including the State Customs Service of Ukraine, approved by the order of the Administration of the State Border Guard Service of Ukraine dated August 29, 2011 № 627 , which stipulates that cooperation is organized to determine the procedure in case officials identify violations of the rules of crossing the 
state border or smuggling and violations of customs rules, coordination of joint actions in the event of conflict and other unusual situations at the checkpoint, the procedure in case of detention of vehicles and goods for violation of applicable law, etc.

According to Yakiv Halaniuk, the main forms of interaction between border and fiscal units are customs control, organization of activities, reconstruction and construction of checkpoints for road transport (Halaniuk, 2018).

Sierykh O.V, considering the issue of cooperation between the bodies of the State Customs Service of Ukraine and the state border guards, quite correctly identifies such a form of cooperation as joint measures to stop violations of legislation on border and customs issues (Sierykh, 2012). In fact, this form of cooperation in identifying signs of violations of customs rules, as well as identifying property that has no owner or whose owner is unknown is regulated by an updated order of the Ministry of Finance of Ukraine and the Ministry of Internal Affairs of Ukraine, which approved Procedure number 849/828.

Such a legal act is not unique in world practice. Thus, at the level of countries adjacent to Ukraine, similar legal acts have been adopted, in particular in the Republic of Belarus (Decree, 2013), (Semenjuk, 2018) and the Russian Federation (Bukanova, 2013). In the Republic of Poland, cooperation is based on the Agreement between the Commander-in-Chief of the Border Guard and the Head of the Main Customs Administration on cooperation between the Border Guard and the Customs Service (Adamchik, 2004). Boykova M.V. talks about the interaction between the border and fiscal units of Finland, although mainly on the fight against crime (Boykova, 2017). On the other hand, cooperation on customs and border issues for countries such as the United States and Canada is not relevant, as customs and border control in these countries is carried out by a single government agency - the Customs and Border Service (in the US) and the Border Services Agency (Canada) (Boykova, 2017).

In this regard, it is expedient to consider the main content of the Procedure number $849 / 828$ and the novelties of this document.

In accordance with the provisions of the Procedure, No. 849/828, as well as under the provisions of the documents in force before its entry into force 
- a joint order of the Ministry of Internal Affairs of Ukraine and the Ministry of Revenue and Duties of Ukraine dated October 3, 2013, No. 947/525 (hereinafter - Instruction, No. 947/525) and the joint order of the State Customs Service of Ukraine and the State Border Guard Service of Ukraine of June 1,2005, No.461/439, in case of detection of state border protection bodies (state border protection units) signs of violation of customs rules between the security body states the boundary (subdivision of the state border) and relevant state customs service of Ukraine organized interaction. As a rule, this is true for detecting signs of violation of customs rules outside the checkpoint across the state border of Ukraine, because at checkpoints across the state border of Ukraine, fiscal authorities have a real opportunity to detect illegal movement of goods and other property. In addition, if the movement of goods and other property is detected outside the checkpoints, the question usually arises about the illegal crossing of the state border by a natural person, because, by virtue of Article 2041 of the Code of Administrative Offenses of Ukraine illegal crossing is considered, including when they are committed in any way outside the checkpoints. Therefore, officials of the State Border Guard Service of Ukraine are obliged to draw up procedural documents in proceedings on administrative offenses - the protocol on administrative offense and the protocol on administrative detention, as well as taking comprehensive measures to detain offenders and goods - objects of the offense, the vehicles in which they moved, as well as accompanying and other documents for the goods, vehicles. The same persons are also obliged to take other actions that are important both to establish the fact of illegal crossing of the state border by a natural person, and to establish the fact of illegal movement of goods and other property across the customs border. At the same time, in case of detection by state border guards (state border guards) of signs of violation of customs rules, the representative of the fiscal authority for the procedural registration of the offense no later than 3 hours must arrive at the scene of the offense (Mota, 2008), (On approval of the Procedure, 2018).

On the other hand, the Procedure No. 849/828 slightly changed the powers of officials of the state border guard bodies during the implementation of such interaction, as well as the places where the appropriate interaction is possible, compared to Instruction number $947 / 525$. 
In particular, the interaction may be carried out by the bodies of the State Customs Service of Ukraine and the bodies of protection of the state border not only at checkpoints across the state border, but also at the entry-exit checkpoint, in the controlled border area (On approval of the Procedure, 2018), through which goods, vehicles and other objects are actually moved, which are not formally moved across the state border, but in fact such movement occurs because these items arrive / leave from / to the territory that is not actually controlled by Ukraine, administrative boundaries partially coincide with the state border of Ukraine, which is not controlled by state border guards and border, fiscal and other types of control are impossible there. In this regard, the implementation of joint activities in these areas, where the bodies of the State Customs Service of Ukraine and the state border guards is important. Only recently the corresponding shortcoming of legislative technique has been eliminated.

In addition, to the powers of an official of the state border guard body (state border guard unit) in case of detection during the operational and service activities outside the checkpoint across the state border of Ukraine, outside the checkpoint entry-exit persons, in the actions of which there are signs of violation of customs rules is attributed in case of detection in the actions of persons offenses, counteraction to which is attributed to the competence of the State Border Guard Service of Ukraine, the right to draw up protocols on administrative detention and registration of cases of administrative offenses (On approval of the Procedure, 2018). Previously, these powers were assigned to the competence of the administrativeoperational group.

In addition, the administrative and operational group of the head of the border service department has the authority to send an act of detection and a copy of the procedural document received from the customs official of the State Customs Service of Ukraine on seizure of objects to the information and analytical unit of the state border guard, storage and mutual reconciliation, and in respect of property the owner, who is unknown or who does not have an owner - transfer of property to the relevant department of the State Customs Service of Ukraine, copies of the relevant act of detection and one of the copies of the act of transfer (On approval of the Procedure, 2018). 
Unfortunately, the Procedure number 849/828 does not contain any other significant changes, although a number of issues related to the interaction of these bodies with the bodies of the State Customs Service of Ukraine arise in the operational and service activities of state border protection bodies.

\section{PROBLEMS OF INTERACTION AT THE STATE BORDER}

In particular, as evidenced by an anonymous survey of staff of the State Border Guard Service of Ukraine with experience working at checkpoints across the state border, the vast majority (over $80 \%$ ) of respondents mentioned the problem of insufficiently effective coordination of the work of state border guards and customs of the State Customs Service of Ukraine on ensuring the unity of customs and border control, which leads to excessive queues at checkpoints, impossibility to send a representative of the State Customs Service of Ukraine or a state border protection body due to the fact that they carry out customs or border control of another person moving goods, vehicles across the state/customs border of Ukraine, lack of interest in such interaction, lack of a specific list of reasons when a joint review should be conducted, the feasibility of increasing the staff in terms of providing in the staff of the relevant unit of persons responsible for conducting a joint review on an ongoing basis. It was also noted that there are no sanctions for failure to conduct a joint inspection in case of detection of goods that move both in violation of customs rules and border legislation without sufficient reasons for this.

In connection with the above, we can offer the following solutions to these problems. The current legislation in general provides for the obligation to inform about the detection of signs of violation of customs rules, property, the owner of which is unknown or which does not have the owner of the responsible persons of the State Customs Service of Ukraine and state border guards, as well as the responsibilities of the administrative task force to inspect the relevant property.

On the other hand, it is expedient to provide for the establishment of a Joint Customs and Border Control Group consisting of the Administra- 
tive Task Force and responsible customs officers of the State Customs Service of Ukraine, which should be empowered to inspect detected property and draw up acts on detection of property, seizure of relevant property, objects of the offense and relevant documents, obtaining appropriate explanations from participants and witnesses of the offense, as well as their subsequent transfer to the customs of the State Customs Service of Ukraine. At the same time, the task of state border guards should be only to stop the offense, detain the perpetrators and ensure the safety of relevant property, vehicles, objects of the offense and relevant documents until the arrival of representatives of fiscal authorities and the creation of a Joint Group, as well as registration of protocols on administrative offenses in case of detection of offenses in the actions of persons whose counteraction is attributed to the competence of the State Border Guard Service of Ukraine, the task of customs officials of the State Customs Service of Ukraine - registration of procedural documents in case of violation of customs rules. In this case, failure to conduct a joint inspection by border and fiscal units will be illegal, and therefore the perpetrators may be subject to disciplinary action. At the same time, in order to ensure the continuity of control, it is advisable to provide separately in the staff of the State Border Guard and Customs of the State Customs Service of Ukraine persons who should be included in the Joint Group and will not be involved in other activities.

\section{CONCLUSIONS}

Based on the above, it can be concluded that the issues of cooperation between state border guards and customs of the State Customs Service of Ukraine are regulated by the updated Procedure No. 849/828, approved by a joint order of the Ministry of Internal Affairs and the Ministry of Finance of Ukraine, which contains a number of novelties, in particular in the transfer of a number of powers from the administrative task force to draw up protocols on administrative offenses, sending an act of detection, and on property owner, unknown or ownerless - transfer of property to the State Customs Service of Ukraine, to other officials of state border 
guards, and also extended the validity of this document not only to cases of violations of customs rules, property, the owner of which has no owner or whose owner is unknown, found at checkpoints across the state border of Ukraine, but also for similar cases detected at an entry-exit checkpoint in a controlled border area.

Unfortunately, the mentioned Procedure No. 849/828 does not solve a number of urgent issues of such interaction, such as: insufficiently effective coordination of the work of state border protection bodies and customs of the State Customs Service of Ukraine on issues of ensuring the unity of customs and border control, impossibility to send a representative of the state border protection bodies (state border protection units) and customs of the State Customs Service of Ukraine, to conduct separate control in cases when it is necessary to conduct joint control, lack of interest in carrying out such interaction, lack of a specific list of reasons when a joint inspection should be conducted, lack of sanctions for failure to conduct a joint inspection in case of detection of goods, who move both in violation of customs regulations and border legislation without sufficient reasons for this. Therefore, a solution to these problems is proposed.

\section{BIBLIOGRAPHY:}

Aurelija Pūraite, Saulius Greičius, Danguolè Seniutienè (2017). Managing State Border in the Context of Migration Crisis in Europe. Lithuanian Case. Montenegrin Journal of Economics, vol. 13, no. 3, pp. 31-42.

Bobrova, O.G., Kozhankov, A. A.Ju., Korovjakovskij, D.G. (2017). Coordinated border management: international standards and law enforcement practice. Moscow: Prometey. (in Russian).

General Results on the activities of the State Border Guard Service of Ukraine in 2019 (2019). State Border Guard Service of Ukraine. Retrieved from: https://dpsu.gov.ua/ upload/infografika_2019_na_sayt.pdf.

Pryimachenko, D.V. (2014). Informing as a form of interaction between revenue and fee bodies in the process of customs procedures. Finance law, no. 3, pp. 25-29.

Protocol amending the Marrakech Agreement Establishing the World Trade Organization (2014). Legislation of Ukraine. Retrieved from: https://zakon.rada.gov.ua/laws/ show/981_053. 
Halaniuk Ya, S. (2018). Fields of interaction of the State Border Guard Service of Ukraine with public authorities in the field of border security. Bulletin of the NAPA under the President of Ukraine (Series «Public Administration»), no. 2, pp. 41-47.

Sierykh, O.V. (2012). Some issues of interaction of customs authorities with state border guard authorities. Scientific herald of Uzhgorod National University. Series Law, no. 19, vol. 3, pp. 198-200.

Ministry of Health of the Republic of Belarus (2013). Decree of the Ministry of Health of the Republic of Belarus, State Customs Committee of the Republic of Belarus, State Border Committee of the Republic of Belarus of December 30, 2013 No. 135/34/16 "On Approval of the Instruction on the Procedure for Actions (Interaction) of the Customs Authorities of the Republic of Belarus, Border Service of the Republic Belarus, bodies and institutions that carry out state sanitary inspection, when conducting sanitary and quarantine control at checkpoints across the state border of the Republic and Belarus". The official website of the State Customs Committee of Belarus. Retrieved from: http://www.customs.gov.by/images/storage/simplecatalog/000223 565753.doc.

Semenjuk, D.P. (2018). The concept and legal basis for the interaction of the bodies of the border service and the customs authorities in the fight against crime. Proceedings of the Border services of the Republic of Belarus: history and modernity (Moscow, Minsk, 03.05.2018). (eds. Grishko V.D.). Minsk: GUO “IPS RB”, part 1, pp. 290-293.

Bukanova, O.A. (2013). On the interaction of border guard service personnel carrying out border control and customs officers of the Federal Customs Service of the Russian Federation at checkpoints across the state border of the Russian Federation. Military Law Journal, no. 6, pp. 2-4.

Adamchik, M., Tkach, A. (2004). Border Guard of the Republic of Poland: Modern European Border Guard Service. Published by the OSCE Office for Democratic Institutions and Human Rights (ODIHR). Warsaw: Pebekom. 97 p.

Bojkova, M.V. (2017). Foreign experience of customs administration. Under total ed. V.V. Makrusev. M.: Publ. Russian Customs Academy. 130 p.

Mota, A.F. (2008). Fight is against Contraband Goods in Activity Government Boundary Service of Ukraine: Organizational and Judicial Aspects. Forum of law, no. 3, pp. 374379. Retrieved from: http://www.nbuv.gov.ua/e-journals/FP/2008-3/08maftpa.pdf.

Ministry of Finance of Ukraine and the Ministry of Internal Affairs of Ukraine (2018). On approval of the Procedure for cooperation between the bodies of the State Border Guard Service of Ukraine and the State Fiscal Service of Ukraine in identifying signs of violations of customs rules, as well as identifying property that is not owned by the owner or whose owner is unknown: an order of the Ministry of Finance of Ukraine and the Ministry of Internal Affairs of Ukraine dated 18.10.2018, No. 849/828. Official Bulletin of Ukraine, art. 3208, No. 97, p. 30. 